\title{
Determination of Impurities in High Purity Germanium by Inductively Coupled Plasma Quadrupole Mass Spectrometry (ICP-QMS) After Matrix Volatilization Using Chlorine Gas
}

\author{
M.A. Reddy, R. Shekhar*, and Sunil Jai Kumar \\ National Centre for Compositional Characterization of Materials (NCCCM) \\ Bhabha Atomic Research Centre, Hyderabad 500 062, India
}

\section{INTRODUCTION}

Germanium (Ge) finds many applications in the electronics industry, medicine, and gamma spectroscopy. The electronics industry uses germanium semiconductor materials in the form of transistors, high-speed integrated circuits (SiGe), solar electrical parts, etc. Germanium also finds applications in extremely sensitive infrared detectors, gamma-ray detectors and phosphor agents in fluorescent lamps, fiber-optic systems, and polymerization catalysts (1-4). Additionally, Ge substrates offer certain advantages over GaAs substrates: high crystallographic perfection, high mechanical strength, and the ability to recycle germanium. These factors have led to a wide use of Ge wafers as a substrate for GaAs in telecommunication satellites (5). Generally, the crystal pulling technique, namely the Czochralski method, is used to make at least $6 \mathrm{~N}$ pure germanium. The impurities present in the germanium samples can produce deeplevel states in the band-gap which can act as recombination centers or carrier traps, thereby degrading the semiconductor properties (6-7).

In view of the above applications, it is essential that the analysis of high purity germanium meet the challenges and highest demands for the global market. Several analytical techniques have been developed for the determination of trace constituents in high

\footnotetext{
*Corresponding author.

E-mail: shekhar_raparthi@rediffmail.com
}

\begin{abstract}
An analytical method is described for the determination of trace level impurities in high purity germanium using quadrupole ICP-MS. Nearly 40 impurities were determined using a method involving matrix volatilization, followed by ICPQMS determination. Chlorine gas generated in situ was used to remove the germanium matrix at $120^{\circ} \mathrm{C}$ as germanium chloride from its impurities without the need for sample digestion in acids. This method resulted in very low process blanks for all the analytes.

The recovery of the impurities was studied and found to be quantitative. The method also provided the quantitative recovery for some elements such as B, $\mathrm{Sn}$, and $\mathrm{Tl}$ whose chlorides are volatile at $120^{\circ} \mathrm{C}$. Spectral interferences arising from the presence of the matrix element at high concentration levels and the discharge gas are discussed. In the absence of certified reference materials for high purity germanium, the accuracy of the method was established by spike recovery tests. The precision of the method was found to vary from 1 to $10 \%$ for concentrations between 1 and $1000 \mathrm{ng} \mathrm{g}^{-1}$. The limits of detection (LODs) for the target analytes were found to be between $0.04-9.0 \mathrm{ng} \mathrm{mL} \mathrm{m}^{-1}$.
\end{abstract}

purity germanium. Among them are neutron activation analysis (NAA) $(8,9)$, photoelectron spectroscopy (10), atomic absorption spectrometry (AAS) (11-13), atomic emission spectrometry (AES) (14), and spark source mass spectrometry (11) used for the characterization of high purity germanium. Graphite furnace atomic absorption spectrometry (GFAAS) is a sensitive analytical technique, but it is a single elemental analytical technique and thus requires a significant amount of time to determine all the impurities in a Ge sample. Although the sensitivities of ICP-OES are not as great as for GFAAS, it is a multielemental technique and provides the concentrations for major to minor level impurities.

Inductively coupled plasma mass spectrometry (ICP-MS) is a sensitive and multi-elemental analytical technique that can determine the concentrations of impurities at trace and ultra-trace levels but can tolerate solutions containing only up to a maximum of $0.1 \%$ total dissolved solids (15-17). This drawback demands the separation of the Ge matrix from its impurities. Chemical separation of the matrix from all other minor or trace constituents is not possible in a single step. Many separation procedures found in the literature are suitable only for a group of elements at a time. Thus, trace element group separations using co-precipitation, solvent extraction, and ion exchange methods are often required. A distillation method reported was used to separate the germanium matrix as $\mathrm{GeCl}_{4}$ from its impurities (18). Later, a closed-vessel microwave-assisted volatilization of $\mathrm{Ge}$ and Se as their chlorides in the presence of aqua regia vapors and determination by ICP-MS was published (19). 
Recently, two matrix separation procedures were reported (20) for the GFAAS determination of critical impurities such as $\mathrm{Cr}, \mathrm{Cu}, \mathrm{Fe}, \mathrm{Ni}$, and $\mathrm{Pb}$ in a germanium matrix. The first procedure involves cloud point extraction, which uses the ammonium pyrrolidine dithiocarbamate (APDC) - Triton ${ }^{\circledR} \mathrm{X}-114$ system, and the second procedure uses a matrix volatilization technique for the removal of the germanium matrix with chlorine gas and determination by GFAAS. However, only a few impurity elements $(\mathrm{Cr}, \mathrm{Cu}$, $\mathrm{Fe}, \mathrm{Ni}, \mathrm{Pb}$ ) were compared and reported (20). To our knowledge, there are no reports in the literature about the determination of impurities in high purity germanium by ICP-QMS using the matrix volatilization procedure.

In this paper, we report the ICPQMS determination of impurities in high purity germanium after matrix volatilization with chlorine gas. Extending the earlier reported matrix volatilization procedure (20) for more than 40 impurities in high purity germanium, quantification was performed by ICP-QMS as the levels of many of the impurities are extremely low. Potential spectral interferences due to discharge gas and matrix have been identified and presented, and the salient features of the method reported.

\section{EXPERIMENTAL}

\section{ICP-QMS Analysis}

A VG Plasma Quad PQ3 inductively coupled plasma quadrupole mass spectrometer (ICP-QMS) (V.G. Elemental, U.K.) was used for the analyte determinations. The ICPQMS conditions were optimized for maximum sensitivity using a $10 \mathrm{ng} \mathrm{mL} \mathrm{mL}^{-1}$ tuning solution of Be, $\mathrm{Co}, \mathrm{In}$, and $\mathrm{Bi}$ in $2 \% \mathrm{HNO}_{3}$. The optimum operating conditions of the ICP-QMS and the typical measurement parameters are listed in Table I. Sample introduction was carried out by pneumatic nebuliza- tion using a Meinhard ${ }^{\circledR}$ concentric nebulizer (sample uptake rate 0.3 $0.4 \mathrm{~mL} \mathrm{~min}^{-1}$ ), a double-pass Scotttype spray chamber cooled to $4^{\circ} \mathrm{C}$ using a NESLAB recirculating chiller, and a Fassel-type torch. Rhodium was used as the internal standard for all of the samples. Mass spectra were obtained in the peak hopping mode.

\section{Standard Solutions and Reagents}

Stock standards of $1 \mathrm{mg} \mathrm{mL}^{-1}$ for each analyte were procured from M/s Merck (Germany). Sub-boiled acids $\left(\mathrm{HNO}_{3}, \mathrm{HCl}\right)$, prepared in our laboratory using quartz sub-boiling units, were used for all of the experiments. Ultra-pure water (>18 M $\Omega$ resistivity) was obtained with a combination of reverseosmosis (RO) system mixed-bed ion-exchanger and a Milli-Q ${ }^{\mathrm{TM}}$ water purification system (Millipore, Bangalore, India). Working standards were prepared by sequential dilutions of the stock standards on a day-to-day basis and added with rhodium as an internal standard (10 $\mathrm{ng} \mathrm{mL}^{-1}$ ).

\section{Matrix Separation Procedure}

Approximately $600 \mathrm{mg}$ of a high purity germanium sample was taken into a pre-cleaned quartz boat on a class 10 clean bench. The boat was carried in a cleaned PFA screw cap container to the experimental setup (placed in a normal fume hood) and then placed in the reaction vessel. Then $30 \mathrm{~g}$ of manganese dioxide was added to $100 \mathrm{~mL}$ of concentrated $\mathrm{HCl}$ in a $1000-\mathrm{mL}$ round bottom flask in a heating mantel and heated slowly up to $75-85^{\circ} \mathrm{C}$. As the temperature increased, chlorine gas slowly evolved and passed through two consecutive concentrated $\mathrm{H}_{2} \mathrm{SO}_{4}$ traps along with the argon carrier gas. This dry chlorine gas was passed into a reaction vessel containing the high purity germanium sample in a quartz boat. The above reaction vessel was maintained at a temperature of $120 \pm 5{ }^{\circ} \mathrm{C}$ for four hours. Initially, the time required to remove the germanium matrix (i.e., Ge to react and disappear) was optimized by taking $600 \mathrm{mg}$ of the germanium sample. It was observed that after four hours, only the weight loss of the sample boat remained constant (i.e., no further loss of Ge). After complete evaporation of the germanium matrix as a chloride, the quartz boat, containing approximately $4 \mathrm{mg}$ residue, was transported into a cleaned PFA container to a class 10 clean bench; the residue was dissolved with $100 \mu \mathrm{L}$ each of sub-boiled $\mathrm{HNO}_{3}$ and $\mathrm{HCl}$. After separating the

TABLE I

ICP-QMS Operating Conditions

\begin{tabular}{ll}
\hline Plasma RF power & $1350 \mathrm{~W}$ \\
Reflected power & $<10 \mathrm{~W}$ \\
Torch & VG / Fassel \\
Coolant argon flow rate & $15.5 \mathrm{~L} \mathrm{~min}^{-1}$ \\
Auxiliary argon flow rate & $0.81 \mathrm{~L} \mathrm{~min}^{-1}$ \\
Double pass spray chamber & $4^{\circ} \mathrm{C}$ \\
Peristaltic pump & Gilson Minipuls $3^{-1}$ \\
Sample uptake & $0.5 \mathrm{~mL} \mathrm{~min}^{-1}$ \\
Nebulizer & Meinhard TR-35-1F1 \\
Ni sample cone orifice & $1.0 \mathrm{~mm}^{\mathrm{F}}$ \\
Ni skimmer cone orifice & $0.75 \mathrm{~mm}^{2}$ \\
Detector Mode & Dual Mode (PC/Analog) \\
\hline
\end{tabular}


matrix, the residue solution containing the trace elements, along with rhodium as internal standard, was passed into the ICP-QMS after suitable dilution. For some of the elements for which the isotopes with the highest abundance suffered from spectral interferences, alternative isotopes of lower abundance having minimum or no isobaric interferences were chosen for quantitation. The quantification of the trace elements in the germanium sample was done using external calibrations.

\section{RESULTS AND DISCUSSION}

\section{Matrix Separation Method}

The matrix volatilization procedure (20) was investigated for the separation of more than $40 \mathrm{impu}-$ rity elements from the germanium matrix. These studies were carried out using a high-purity germanium sample of around $6 \mathrm{~N}$ purity. The germanium matrix was separated from its trace elements in the form of germanium chloride at $120^{\circ} \mathrm{C}$ after it reacted with chlorine gas, which was generated in situ from the reaction of manganese dioxide and hydrochloric acid. The percentage removal of the germanium matrix was determined by inductively coupled plasma optical emission spectrometry (ICP-OES) and found to be $99.5 \pm 0.2 \%(\mathrm{~N}=4)$. Since many (other) elements will not form chlorides at that temperature, they remain in the sample boat. Therefore, the impurities of the germanium matrix could be separated from the matrix. The percentage separation (recovery) of 41 analytes was examined by adding known amounts (100 ng absolute) of analytes (Li, Be, B, Mg, Al, P, Si, Sc, Ti, V, Cr, Mn, Fe, Co, Ni, Cu, Zn, $\mathrm{Ga}, \mathrm{As}, \mathrm{Se}, \mathrm{Mo}, \mathrm{Sr}, \mathrm{Ru}, \mathrm{Ag}$, In, Cd, Sn, $\mathrm{Sb}, \mathrm{Te}, \mathrm{Cs}, \mathrm{Ba}, \mathrm{Ta}, \mathrm{W}, \mathrm{Re}, \mathrm{Ir}, \mathrm{Pt}, \mathrm{Au}$, $\mathrm{Hg}, \mathrm{Tl}, \mathrm{Pb}, \mathrm{Bi}$ ) to the germanium sample prior to performing the matrix volatilization procedure. An aliquot of $100 \mu \mathrm{L}$ of mixed standard solution containing each element of $1 \mu \mathrm{g} \mathrm{mL} \mathrm{m}^{-1}$ concentration was added to the cleaned empty sample boat. The solution was evaporated slowly to dryness by an infrared lamp. Then the germanium sample in smalllumps form was added to the sample boat and then allowed to react with chlorine gas in the reaction vessel. Since the melting point of germanium is high $\left(938.25^{\circ} \mathrm{C}\right)$, the germanium sample was not melted to spike the analytes. The residue containing the actual impurities, as well as the spiked analytes, was dissolved in $\mathrm{HCl}$ and $\mathrm{HNO}_{3}$ media and, after suitable dilutions ( 1 - $5 \mathrm{ng} \mathrm{mL}^{-1}$ levels), passed into the ICP-QMS along with the standard solutions. The recoveries of the analytes were computed and are listed in Table II.

The results in Table II reveal that 39 of the analytes ( $\mathrm{Li}, \mathrm{Be}, \mathrm{B}, \mathrm{Mg}, \mathrm{Al}$, $\mathrm{Sc}, \mathrm{Ti}, \mathrm{V}, \mathrm{Cr}, \mathrm{Mn}, \mathrm{Fe}, \mathrm{Co}, \mathrm{Ni}, \mathrm{Cu}, \mathrm{Zn}$, $\mathrm{Ga}, \mathrm{As}, \mathrm{Se}, \mathrm{Mo}, \mathrm{Sr}, \mathrm{Ag}, \mathrm{Ru}, \mathrm{In}, \mathrm{Cd}$, Sn, Sb, Te, Cs, Ba, Ta, W, Re, Ir, Pt, $\mathrm{Au}, \mathrm{Hg}, \mathrm{Tl}, \mathrm{Pb}, \mathrm{Bi}$ - except for $\mathrm{P}$ and $\mathrm{Si}$ ) were quantitatively separated from the germanium matrix. This can be attributed to the melting or boiling points of their chlorides which are greater than $120^{\circ} \mathrm{C}$ (see Table III). Therefore, the chlorides of these elements, if formed, were not lost along with germanium chloride and, hence, remained in the sample boat of the reaction vessel. Some of the elements $(\mathrm{P}, \mathrm{Si})$, whose chlorides have melting or boiling points less than $120^{\circ} \mathrm{C}$ (Table IV), are volatilized and lost from the reaction vessel along with germanium chloride. In the presence of chlorine gas, only phosphorus trichloride is produced. Hence, the recoveries of these elements were not found to be quantitative. For some of the elements (B, Sn, Tl), even though their chlorides have melting/boiling points less than $120^{\circ} \mathrm{C}$ (Table IV), their recoveries were found to be quantitative. Boron trichloride is not formed in the reaction vessel because it is pro- duced with chlorine gas only at $500{ }^{\circ} \mathrm{C}$ in the presence of carbon. In case of tin and thallium, tin(IV) chloride and thallium(III) chloride, which have melting/boiling points of less than $120^{\circ} \mathrm{C}$ (Table IV), are not formed. The experimental results (i.e., quantitative recoveries) for these two elements indicate that tin(II) chloride and thallium(I) chloride, which have melting points above $120^{\circ} \mathrm{C}$ (Table III), are formed. The formation of tin(II) chloride and thallium(I) chloride in the reaction vessel is also supported in the literature $(21,22)$. That is, in the presence of hydrochloric acid (vapors), tin forms tin(II) chloride and thallium forms thallium(I) chloride. Vapors of hydrochloric acid, generated from the concentrated $\mathrm{HCl}$ solution being used for in situ generation of chlorine gas, is carried away along with the argon carrier gas. Therefore, there is no loss of tin and thallium as chlorides. In the case of arsenic, whose boiling point of $130^{\circ} \mathrm{C}$ is near the temperature of the reaction vessel of $120{ }^{\circ} \mathrm{C}$, some fraction of its chloride is lost along with the germanium chloride. Hence, its recovery was found to be less than $75 \%$.

\section{Spectral Interferences}

In ICP-MS analysis, the dominant spectral interferences are due to water, acids used for preparation, entrained atmospheric gases, and argon (discharge gas). Major polyatomic ions observed in the ICPQMS analysis of the germanium sample are listed in Table V. These polyatomic ions are interfering the isotopes ${ }^{48} \mathrm{Ti},{ }^{52} \mathrm{Cr},{ }^{54} \mathrm{Fe},{ }^{56} \mathrm{Fe},{ }^{69} \mathrm{Ga}$, ${ }^{75} \mathrm{As},{ }^{77} \mathrm{Se},{ }^{78} \mathrm{Se},{ }^{80} \mathrm{Se},{ }^{81} \mathrm{Se},{ }^{90} \mathrm{Zr},{ }^{92} \mathrm{Zr}$, ${ }^{114} \mathrm{Cd}$, and ${ }^{116} \mathrm{Cd}$. After removal of the germanium matrix, the above chloride-related interferences were observed in the ICP-QMS analysis since the residual trace elements were dissolved in $\mathrm{HCl}$ and $\mathrm{HNO}_{3}$ media. In the ICP-QMS analysis of the germanium matrix sample, 
TABLE II

Percentage Recoveries of the Trace Elements in Matrix Volatilization Procedure

\begin{tabular}{|c|c|c|c|c|c|}
\hline $\begin{array}{l}\text { Ele } \\
\text { ment }\end{array}$ & $\begin{array}{l}\text { Added } \\
\text { s Amount } \\
\text { to Sample } \\
\text { (ng) }\end{array}$ & $\begin{array}{l}\text { Obtained } \\
\text { After } \\
\text { Matrix } \\
\text { Separation } \\
(\mathrm{ng}, \mathrm{N}=4)\end{array}$ & $\begin{array}{l}\text { Ele- } \\
\text { ments }\end{array}$ & $\begin{array}{c}\text { Added } \\
\text { Amount } \\
\text { to Sample } \\
\text { (ng) }\end{array}$ & $\begin{array}{l}\text { Obtained } \\
\text { After } \\
\text { Matrix } \\
\text { Separation } \\
(\mathrm{ng}, \mathrm{N}=4)\end{array}$ \\
\hline $\mathrm{Li}$ & 100 & $98 \pm 2$ & $\mathrm{Ru}$ & 100 & $99 \pm 1$ \\
\hline $\mathrm{Be}$ & 100 & $97 \pm 1$ & Ag & 100 & $102 \pm 1$ \\
\hline B & 100 & $93 \pm 1$ & $\mathrm{Cd}$ & 100 & $98 \pm 2$ \\
\hline $\mathrm{Mg}$ & 100 & $98 \pm 1$ & In & 100 & $99 \pm 1$ \\
\hline $\mathrm{Al}$ & 100 & $101 \pm 1$ & Sn & 100 & $90 \pm 2$ \\
\hline Sc & 100 & $100 \pm 2$ & $\mathrm{Sb}$ & 100 & $96 \pm 1$ \\
\hline $\mathrm{Ti}$ & 100 & $100 \pm 1$ & Te & 100 & $96 \pm 2$ \\
\hline V & 100 & $100 \pm 2$ & Cs & 100 & $100 \pm 2$ \\
\hline $\mathrm{Cr}$ & 100 & $96 \pm 2$ & $\mathrm{Ba}$ & 100 & $98 \pm 1$ \\
\hline Mn & 100 & $100 \pm 1$ & W & 100 & $100 \pm 1$ \\
\hline $\mathrm{Fe}$ & 100 & $105 \pm 2$ & $\mathrm{Ta}$ & 100 & $95 \pm 2$ \\
\hline $\mathrm{Ni}$ & 100 & $100 \pm 2$ & $\operatorname{Re}$ & 100 & $99 \pm 1$ \\
\hline Co & 100 & $99 \pm 1$ & Ir & 100 & $100 \pm 1$ \\
\hline $\mathrm{Cu}$ & 100 & $102 \pm 2$ & $\mathrm{Pt}$ & 100 & $95 \pm 1$ \\
\hline $\mathrm{Zn}$ & 100 & $110 \pm 1$ & $\mathrm{Au}$ & 100 & $96 \pm 2$ \\
\hline $\mathrm{Ga}$ & 100 & $105 \pm 1$ & $\mathrm{Hg}$ & 100 & $88 \pm 1$ \\
\hline As & 100 & $75 \pm 2$ & $\mathrm{Tl}$ & 100 & $96 \pm 1$ \\
\hline $\mathrm{Se}$ & 100 & $85 \pm 1$ & $\mathrm{~Pb}$ & 100 & $99 \pm 1$ \\
\hline $\mathrm{Sr}$ & 100 & $98 \pm 2$ & $\mathrm{Bi}$ & 100 & $99 \pm 2$ \\
\hline Mo & 100 & $97 \pm 1$ & & & \\
\hline
\end{tabular}

TABLE IV

List of Elements Whose Chlorides Have Melting/Boiling Points Less than $120{ }^{\circ} \mathrm{C}$

\begin{tabular}{ccc|ccc}
\hline $\begin{array}{c}\text { Ele- } \\
\text { ments }\end{array}$ & $\begin{array}{c}\text { Melting } \\
\text { Point } \\
\left({ }^{\circ} \mathrm{C}\right)\end{array}$ & $\begin{array}{c}\text { Boiling } \\
\text { Point } \\
\left({ }^{\circ} \mathrm{C}\right)\end{array}$ & $\begin{array}{c}\text { Ele- } \\
\text { ments }\end{array}$ & $\begin{array}{c}\text { Melting } \\
\text { Point } \\
\left({ }^{\circ} \mathrm{C}\right)\end{array}$ & $\begin{array}{c}\text { Boiling } \\
\text { Point } \\
\left({ }^{\circ} \mathrm{C}\right)\end{array}$ \\
\hline B & -107 & 13 & Ge(IV) & -51 & 84 \\
P(III) & -92 & 74 & Sn(IV) & -33 & 113 \\
P(V) & 167 & $160^{\mathrm{a}}$ & Tl(III) & -25 & $-\mathrm{b}$ \\
Si(IV) & -67 & 56 & & & \\
\hline
\end{tabular}

a: sublime; ${ }^{\text {b: decompose. }}$
TABLE III

List of Elements Whose Chlorides Have Melting Points/Boiling Points Greater than $120{ }^{\circ} \mathrm{C}$

\begin{tabular}{cc|lc|lc}
\hline $\begin{array}{c}\text { Ele- } \\
\text { ments }\end{array}$ & $\begin{array}{c}\text { Melting } \\
\text { Point } \\
\left({ }^{\circ} \mathrm{C}\right)\end{array}$ & $\begin{array}{c}\text { Ele- } \\
\text { ments }\end{array}$ & $\begin{array}{c}\text { Melting } \\
\text { Point } \\
\left({ }^{\circ} \mathrm{C}\right)\end{array}$ & $\begin{array}{c}\text { Ele- } \\
\text { ments }\end{array}$ & $\begin{array}{c}\text { Melting } \\
\text { Point } \\
\left({ }^{\circ} \mathrm{C}\right)\end{array}$ \\
\hline $\mathrm{Li}$ & 614 & $\mathrm{Zn}$ & 318 & $\mathrm{Cs}$ & 642 \\
$\mathrm{Be}$ & 416 & $\mathrm{Ga}$ & $200^{\mathrm{c}}$ & $\mathrm{Ba}$ & 960 \\
$\mathrm{Mg}$ & 712 & $\mathrm{As}(\mathrm{III})$ & $130^{\mathrm{c}}$ & $\mathrm{Ta}$ & 221 \\
$\mathrm{Al}$ & 192 & $\mathrm{Se}$ & 305 & $\mathrm{~W}$ & 275 \\
$\mathrm{Sc}$ & 960 & $\mathrm{Sr}$ & 872 & $\mathrm{Re}$ & $500^{\mathrm{c}}$ \\
$\mathrm{Ti}$ & $432^{\mathrm{a}}$ & $\mathrm{Mo}$ & 194 & $\mathrm{Ir}$ & $763^{\mathrm{b}}$ \\
$\mathrm{V}(\mathrm{III})$ & $300^{\mathrm{b}}$ & $\mathrm{Ru}$ & $500^{\mathrm{b}}$ & $\mathrm{Pt}$ & $370^{\mathrm{b}}$ \\
$\mathrm{Cr}$ & 824 & $\mathrm{Ag}$ & 455 & $\mathrm{Au}$ & $254^{\mathrm{b}}$ \\
$\mathrm{Mn}$ & 650 & $\mathrm{In}$ & 585 & $\mathrm{Hg}(\mathrm{II})$ & 277 \\
$\mathrm{Fe}$ & 306 & $\mathrm{Cd}$ & 568 & $\mathrm{Tl}(\mathrm{I})$ & 427 \\
$\mathrm{Co}$ & 730 & $\mathrm{Sn}(\mathrm{II})$ & 247 & $\mathrm{~Pb}$ & 492 \\
$\mathrm{Ni}$ & 1000 & $\mathrm{Sb}(\mathrm{III})$ & $223^{\mathrm{c}}$ & $\mathrm{Bi}$ & 230 \\
$\mathrm{Cu}$ & 630 & $\mathrm{Te}$ & 175 & & \\
\hline
\end{tabular}

a: sublime. ${ }^{\text {b: }}$ decompose. ${ }^{\text {c: }}$ boiling point.

TA BLE V

Spectral Interferences Observed in the Analysis of Germanium by ICP-QMS

\begin{tabular}{ccc}
\hline Masses & $\begin{array}{c}\text { Polyatomic } \\
\text { Ions Formed }\end{array}$ & $\begin{array}{c}\text { Interfering } \\
\text { Isotopes }\end{array}$ \\
\hline 48 & ${ }^{36} \mathrm{Ar}^{12} \mathrm{C}^{+}$ & ${ }^{48} \mathrm{Ti}$ \\
52 & ${ }^{40} \mathrm{Ar}^{12} \mathrm{C}^{+}$ & ${ }^{52} \mathrm{Cr}$ \\
54 & ${ }^{40} \mathrm{Ar}^{14} \mathrm{~N}^{+}$ & ${ }^{54} \mathrm{Fe}$ \\
56 & ${ }^{40} \mathrm{Ar}^{16} \mathrm{O}^{+}$ & ${ }^{56} \mathrm{Fe}$ \\
69 & ${ }^{37} \mathrm{Cl}^{16} \mathrm{O}_{2}^{+}$ & ${ }^{69} \mathrm{Ga}$ \\
75 & ${ }^{40} \mathrm{Ar}^{35} \mathrm{Cl}^{+},{ }^{74} \mathrm{Ge}^{1} \mathrm{H}^{+}$ & ${ }^{75} \mathrm{As}$ \\
77 & ${ }^{40} \mathrm{Ar}^{37} \mathrm{Cl}^{+}$ & ${ }^{77} \mathrm{Se}$ \\
78 & ${ }^{40} \mathrm{Ar}^{38} \mathrm{Ar}^{+}$ & ${ }^{78} \mathrm{Se}$ \\
80 & ${ }^{40} \mathrm{Ar}_{2}^{+}$ & ${ }^{80} \mathrm{Se}$ \\
81 & ${ }^{40} \mathrm{Ar}_{2} \mathrm{H}^{+}$ & ${ }^{81} \mathrm{Se}$ \\
90 & ${ }^{74} \mathrm{Ge}^{16} \mathrm{O}^{+}$ & ${ }^{90} \mathrm{Zr}$ \\
92 & ${ }^{76} \mathrm{Ge}^{16} \mathrm{O}^{+}$ & ${ }^{92} \mathrm{Zr}$ \\
114 & ${ }^{74} \mathrm{Ge}^{40} \mathrm{Ar}^{+}$ & ${ }^{114} \mathrm{Cd}$ \\
116 & ${ }^{76} \mathrm{Ge}^{40} \mathrm{Ar}^{+}$ & ${ }^{116} \mathrm{Cd}$ \\
\hline
\end{tabular}




\section{Atomic Apectroscopy \\ 1 Vol. 34(4), July/August 2013}

arsenic $\left({ }^{75} \mathrm{As}^{+}\right)$suffers from spectral interferences due to two polyatomic ions, ${ }^{40} \mathrm{Ar}^{35} \mathrm{Cl}^{+}$and ${ }^{74} \mathrm{Ge}^{1} \mathrm{H}^{+}$. Since the percentage removal of the germanium matrix was found to be $99.5 \pm 0.2 \%(\mathrm{~N}=4)$, the residual germanium matrix present in the solution produced spectral interferences by forming polyatomic ions such as ${ }^{74} \mathrm{Ge}^{1} \mathrm{H}^{+},{ }^{76} \mathrm{Ge}^{16} \mathrm{O}^{+}$,

${ }^{74} \mathrm{Ge}^{40} \mathrm{Ar}^{+}$, and ${ }^{76} \mathrm{Ge}^{40} \mathrm{Ar}^{+}$.

\section{Process Blanks and Limits of Detection of the Method}

The process blanks and the limits of detection (LODs) of the matrix volatilization method were evaluated for all of the analytes. The process blank boat without the germanium sample was treated in the reaction vessel the same way as the sample. The residue, after bringing it into solution, was passed into the ICP-QMS, and the signals for the analytes recorded. The values of the average process blanks $(n=5)$ for all of the analytes are listed in Table VI. The detection limits were computed based on the formula $3 \sigma / \mathrm{m}$ ( $\sigma$ is the standard deviation corresponding to five blank measurements and $\mathrm{m}$ is the slope of the calibration graph of each element). The calibration graph was drawn for the concentration range of 1 to $20 \mathrm{ng} \mathrm{mL}^{-1}$ for each element. The limits of detection achieved for the analytes in the present separation procedure and the detection by ICP-QMS are listed in Table VI. The LODs were found to be at low ppb and sub ppb levels. The process blanks and LODs listed in Table VI indicate that the proposed matrix separation procedure with ICP-QMS determination can be highly useful for the determination of impurities in high purity germanium of $6 \mathrm{~N}$ or better purity.

\section{Quantification of Impurities}

The concentrations of all of the impurities in a germanium matrix sample were quantified using exter-

TABLE VI

Process Blanks and Limits of Detection (LODs) of Proposed Procedure by ICP-QMS

\begin{tabular}{ccl|lll|lcc}
\hline $\begin{array}{c}\text { Ele- } \\
\text { ment }\end{array}$ & $\begin{array}{c}\text { Process } \\
\text { Blank } \\
\left(\mathrm{ng} \mathrm{mL}^{-1}\right)\end{array}$ & LODs & $\begin{array}{l}\text { Ele- } \\
\left.\text { ment } \mathrm{mL}^{-1}\right)\end{array}$ & $\begin{array}{c}\text { Process } \\
\text { Blank } \\
\left(\mathrm{ng} \mathrm{mL}^{-1}\right)\end{array}$ & $\begin{array}{c}\text { LODs } \\
\left(\mathrm{ng} \mathrm{mL}^{-1}\right)\end{array}$ & $\begin{array}{c}\text { Ele- } \\
\text { ment }\end{array}$ & $\begin{array}{c}\text { Process } \\
\text { Blank } \\
\left(\mathrm{ng} \mathrm{mL}^{-1}\right)\end{array}$ & $\begin{array}{c}\text { LODs } \\
\left(\mathrm{ng} \mathrm{mL}^{-1}\right)\end{array}$ \\
\hline $\mathrm{Li}$ & 0.4 & 9 & $\mathrm{Cu}$ & 5.7 & 1 & $\mathrm{Te}$ & 12 & 0.1 \\
$\mathrm{Be}$ & 0.12 & 3 & $\mathrm{Zn}$ & 15 & 0.1 & $\mathrm{Cs}$ & 0.13 & 0.01 \\
$\mathrm{~B}$ & 3.1 & 0.5 & $\mathrm{Ga}$ & 3.4 & 1 & $\mathrm{Ba}$ & 7.2 & 1 \\
$\mathrm{Mg}$ & 17 & 2 & $\mathrm{As}$ & $5.6^{\mathrm{a}}$ & $1^{\mathrm{a}}$ & $\mathrm{Ta}$ & 0.30 & 0.1 \\
$\mathrm{Al}$ & 23 & 2 & $\mathrm{Se}$ & 0.81 & 0.4 & $\mathrm{Re}$ & 0.15 & 0.1 \\
$\mathrm{Sc}$ & 0.48 & 0.2 & $\mathrm{Sr}$ & 0.40 & 0.1 & $\mathrm{Ir}$ & 0.16 & 0.1 \\
$\mathrm{Ti}$ & 21 & 3 & $\mathrm{Mo}$ & 2.5 & 0.1 & $\mathrm{Pt}$ & 0.17 & 0.1 \\
$\mathrm{~V}$ & 68 & 4 & $\mathrm{Ru}$ & 0.13 & 0.1 & $\mathrm{Au}$ & 0.16 & 0.1 \\
$\mathrm{Cr}$ & 5 & 6 & $\mathrm{Ag}$ & 0.11 & 0.1 & $\mathrm{Hg}$ & 0.16 & 0.1 \\
$\mathrm{Mn}$ & 1.7 & 0.1 & $\mathrm{Cd}$ & 3.5 & 2 & $\mathrm{Tl}$ & 0.18 & 0.1 \\
$\mathrm{Fe}$ & $14^{\mathrm{a}}$ & $6^{\mathrm{a}}$ & $\mathrm{In}$ & 0.66 & 0.1 & $\mathrm{~Pb}$ & 2.5 & 0.2 \\
$\mathrm{Co}$ & 15 & 6 & $\mathrm{Sn}$ & 15 & 8 & $\mathrm{Bi}$ & 0.03 & 0.04 \\
$\mathrm{Ni}$ & 4.1 & 1 & $\mathrm{Sb}$ & 0.80 & 0.1 & & & \\
\hline
\end{tabular}

a: By high resolution continuum source atomic absorption spectrometry (HR-CS-AAS).

nal calibrations. The concentrations of some of the elements, whose signals were found to be equal to those of the process blanks, were determined based on the average process blank signal and reported as less than values. For some elements, whose major isotopes suffered from spectral interferences, alternative isotopes with minimum or no isobaric interferences were used for quantitation. Iron and arsenic could not be quantified by using quadrupole ICP-QMS due to spectral interferences. However, quantification of these elements can be possible by ICP-MS equipped with dynamic reaction cell $^{\mathrm{TM}}$ (DRC ${ }^{\mathrm{TM}}$ ICP-MS). In the absence of DRC ICP-MS at our laboratory, an alternative sensitive technique of high resolution continuum source atomic absorption spectrometry (HR-CS-AAS) was used for the measurement and quantification of these two elements.

The concentrations of the impurities in a high purity germanium sample, quantified by ICP-QMS and
HR-CS-AAS after the matrix volatilization procedure, are given in Table VII. Since certified reference materials for high purity germanium are not available, the reliability and accuracy of the method was verified by recovery experiments. The high purity germanium samples were spiked with standard solutions of all of the analytes before applying the matrix volatilization procedure. The recoveries were determined and found to be between 85 - 110\% (Table II).

These values show that the proposed method can be applied for the separation/preconcentration of the target analytes.

The present ICP-QMS method provided better detection limits for the elements $\mathrm{Cr}, \mathrm{Cu}, \mathrm{Fe}, \mathrm{Ni}, \mathrm{Pb}$ in comparison to the matrix volatilization procedure (20) by GFAAS. The precision, expressed as the percentage relative standard deviation (\%RSD) of the signals, obtained with multiple sample loadings $(\mathrm{N}=4)$, was determined and found to vary from 1 to $10 \%$ for concentrations between 1 to $1000 \mathrm{ng} \mathrm{g}^{-1}$. 
TABLE VII

Trace Element Concentrations of High Purity Germanium Determined by ICP-QMS through Matrix Volatilization

\begin{tabular}{lc|cc}
\hline Elements & $\begin{array}{c}\text { ICP-MS } \\
\left(\mu \mathrm{g} \mathrm{g}^{-1}\right)\end{array}$ & Elements & $\begin{array}{c}\text { ICP-MS } \\
\left(\mu \mathrm{g} \mathrm{g}^{-1}\right)\end{array}$ \\
\hline $\mathrm{Li}$ & $0.007 \pm 0.001$ & $\mathrm{Ru}$ & $<0.001$ \\
$\mathrm{Be}$ & $0.007 \pm 0.001$ & $\mathrm{Ag}$ & $0.007 \pm 0.001$ \\
$\mathrm{~B}$ & $0.010 \pm 0.001$ & $\mathrm{Cd}$ & $0.030 \pm 0.001$ \\
$\mathrm{Mg}$ & $0.50 \pm 0.02$ & $\mathrm{In}$ & $0.010 \pm 0.001$ \\
$\mathrm{Al}$ & $0.30 \pm 0.01$ & $\mathrm{Sn}$ & $0.25 \pm 0.01$ \\
$\mathrm{Sc}$ & $0.007 \pm 0.001$ & $\mathrm{Sb}$ & $0.007 \pm 0.001$ \\
$\mathrm{Ti}$ & $0.07 \pm 0.01$ & $\mathrm{Te}$ & $0.020 \pm 0.001$ \\
$\mathrm{~V}$ & $0.23 \pm 0.01$ & $\mathrm{Cs}$ & $0.020 \pm 0.001$ \\
$\mathrm{Cr}$ & $0.09 \pm 0.01$ & $\mathrm{Ba}$ & $0.15 \pm 0.01$ \\
$\mathrm{Mn}$ & $0.070 \pm 0.001$ & $\mathrm{Ta}$ & $1.6 \pm 0.3$ \\
$\mathrm{Fe}$ & $1.0 \pm 0.1$ & $\mathrm{~W}$ & $<0.001$ \\
$\mathrm{Ni}$ & $0.07 \pm 0.01$ & $\mathrm{Re}$ & $<0.001$ \\
$\mathrm{Co}$ & $0.006 \pm 0.001$ & $\mathrm{Ir}$ & $<0.001$ \\
$\mathrm{Cu}$ & $0.70 \pm 0.01$ & $\mathrm{Pt}$ & $<0.001$ \\
$\mathrm{Zn}$ & $0.12 \pm 0.01$ & $\mathrm{Au}$ & $0.001 \pm 0.0001$ \\
$\mathrm{Ga}$ & $0.70 \pm 0.02$ & $\mathrm{Hg}$ & $0.001 \pm 0.0001$ \\
$\mathrm{As}$ & $0.020 \pm 0.002$ & $\mathrm{Tl}$ & $<0.001$ \\
$\mathrm{Se}$ & $0.005 \pm 0.01$ & $\mathrm{~Pb}$ & $0.03 \pm 0.01$ \\
$\mathrm{Sr}$ & $0.030 \pm 0.001$ & $\mathrm{Bi}$ & $<0.001$ \\
$\mathrm{Mo}$ & $<0.003$ & & \\
\hline & & &
\end{tabular}

\section{CONCLUSION}

An analytical method using quadrupole ICP-MS has been established for the determination of impurities in a high purity germanium matrix of $6 \mathrm{~N}$ purity. About 40 impurity elements were determined by the proposed method without requiring acidic sample digestion. This method resulted in very low process blanks and provides limits of detection at low ppb and sub ppb levels for all of the analytes. The method also proved that the chlorides of B, Sn, and Tl were not formed in the reaction vessel in the presence of chlorine gas, resulting in a quantitative recovery for these elements whose chlorides have boiling points of less than at $120^{\circ} \mathrm{C}$. This work also demonstrates the feasibility of the method.
Modern instruments such as DRC ${ }^{\text {TM }}$ ICP-MS or high resolution ICP-MS can overcome some of the limitations (e.g., spectral interferences) of the method. Good repeatability in percentage removal of the germanium matrix as well as in the recovery of the trace elements was obtained. Therefore, the proposed method is quite useful for the purity assessment of germanium semiconductor material of $6 \mathrm{~N}$ or better purity.

$\overline{\text { Received March 26, } 2013 .}$

\section{REFERENCES}

1. M.U. Khandaker, International Journal of Fundamental Physical Sciences 1, 42 (2011).
2. R.D. Baertsch and R.N. Hall, IEEE Trans. Nucl. Sci. 17, 235 (1971).

3. E. Sakai, T.A. McMath and I.L. Fowler, IEEE Trans. Nucl. Sci. 18, 228 (1971).

4. W.E. Drummond, IEEE Trans. Nucl. Sci. 18, 91 (1971).

5. J. Derluyn, K Dessein, G Flamand, Y Mols, J Poortmans, G Borghs, J Cryst Growth 247, 237 (2003).

6. T. Hackbarth, G. Hoeck, H.J. Herzog and M. Zeuner, J.Crystal Growth 734, 201 (1999).

7. P. Clauws and E. Simoen, Mat. Sci. Semicon. Proc. 9, 546 (2006).

8. G.N. Razumova, I.D. Shuba, and I. Vasiliev, Radiokhimiya 12, 133 (1970).

9. M.I. Ginzburg, N.I. Marunina, and E.S. Milenin, Tsvetn. Metall. 1, 56 (1977).

10. E.M. Bykova, M.I. Iglytsin, E.A. Kurkova, D.I. Levinzov, V.I. Sidorov, and V.A. Shershel, Zavod. Lab. 42, 415 (1976).

11. P. Murugaiyan, Pure Appl. Chem. 54, 835 (1982).

12. V.G. Pimenov and D.A. Timovin, Vysokochist Vesh-chestva 1, 149 (1988).

13. E. Sentimenti, G. Mazzetto, J. Anal. At. Spectom. 8, 89 (1993).

14. V.G. Pimenov, A.N. Pronchatov, G.A. Maksimov, V.N. Shishov, E.M. Shcheplyagin and S.G. Krasnova, Zh. Anal. Khim. 39, 1636 (1984).

15. M. Nicolai, C. Rosin, N. Tousset, Y. Nicolai, Talanta 50, 433 (1999).

16. D. Beauchemin, J.W. McLarent and S.S. Berman. Spectrochimica Acta 42B, 467 (1987).

17. S. Salomon, V. Jenne and M. Hoenig, Talanta 57, 157 (2002).

18. C.L.Luke and M.E. Campbell, Anal. Chem. 25, 1588 (1953).

19. R.L. Ueng, A.C. Sahayam, S.J. Jiang and C.C. Wan. J. Anal. At. Spectrom. 19, 681 (2004).

20. M.A. Reddy, N.N. Meeravali and Sunil Jai Kumar, At. Spectrosc. 30, 92 (2009).

21. http://en.wikipedia.org/wiki/Tin(II)_ chloride

22.http://en.wikipedia.org/wiki/Thallium (I)_chloride 